\title{
Regulation of Plant Responses to Salt Stress
}

\author{
Shuangshuang Zhao ${ }^{1, *}$, Qikun Zhang ${ }^{1}$, Mingyue Liu ${ }^{1}{ }^{\oplus}$, Huapeng Zhou ${ }^{2}\left(\right.$, Changle Ma $^{1}$ and Pingping Wang ${ }^{1, *}$ \\ 1 Shandong Provincial Key Laboratory of Plant Stress, College of Life Sciences, Shandong Normal University, \\ Jinan 250014, China; zhangqikun1016@163.com (Q.Z.); lmy312325@163.com (M.L.); \\ machangle@sdnu.edu.cn (C.M.) \\ 2 Key Laboratory of Bio-Resource and Eco-Environment of Ministry of Education, College of Life Sciences, \\ Sichuan University, Chengdu 610064, China; zhouhuapeng@scu.edu.cn \\ * Correspondence: zhaoshuangqw12@163.com (S.Z.); pingping.wang@sdnu.edu.cn (P.W.); \\ Tel.: +86-531-8618-0792 (S.Z.); Fax: +86-531-8618-0792 (P.W.)
}

check for updates

Citation: Zhao, S.; Zhang, Q.; Liu,

M.; Zhou, H.; Ma, C.; Wang, P.

Regulation of Plant Responses to Salt Stress. Int. J. Mol. Sci. 2021, 22, 4609. https://doi.org/10.3390/ijms22094609

Academic Editors:

Mirza Hasanuzzaman and

Masayuki Fujita

Received: 14 March 2021

Accepted: 23 April 2021

Published: 28 April 2021

Publisher's Note: MDPI stays neutral with regard to jurisdictional claims in published maps and institutional affiliations.

Copyright: (c) 2021 by the authors. Licensee MDPI, Basel, Switzerland. This article is an open access article distributed under the terms and conditions of the Creative Commons Attribution (CC BY) license (https:// creativecommons.org/licenses/by/ $4.0 /)$.

\begin{abstract}
Salt stress is a major environmental stress that affects plant growth and development. Plants are sessile and thus have to develop suitable mechanisms to adapt to high-salt environments. Salt stress increases the intracellular osmotic pressure and can cause the accumulation of sodium to toxic levels. Thus, in response to salt stress signals, plants adapt via various mechanisms, including regulating ion homeostasis, activating the osmotic stress pathway, mediating plant hormone signaling, and regulating cytoskeleton dynamics and the cell wall composition. Unraveling the mechanisms underlying these physiological and biochemical responses to salt stress could provide valuable strategies to improve agricultural crop yields. In this review, we summarize recent developments in our understanding of the regulation of plant salt stress.
\end{abstract}

Keywords: salt stress; ion transport; osmotic homeostasis; hormone mediation; cell wall regulation

\section{Introduction}

The demands on crop yield have risen sharply worldwide to keep up with the rapidly expanding human population over the past twenty years [1]. Thus, how to improve crop yield and quality has become an urgent global agricultural problem. Soil salinization is a major environmental challenge that is threatening agriculture across the world [2]. Approximately $20 \%$ of the world's irrigated agricultural lands are adversely affected by soil salinization [3]. Issues with soil salinization are aggravated by natural environment deterioration, poor irrigation practices, and climate changes [4,5]. Thus, to effectively improve crop yields, it is critical to address the increasingly serious threat of soil salinization.

Two kinds of plants exist: halophytes and glycophytes. Halophytes are salinitytolerant plants, which have adapted to salinized environments and even benefit from high salt concentrations for optimal growth [6]. In contrast, glycophytes are salinity-sensitive plants, in which growth and development are adversely inhibited by soil salinization [7]. Most crops are glycophytes. High salinity hampers glycophytes' growth and development, seriously limiting crop productivity and challenging food security. The cultivation and development of salt-tolerant crop varieties are key strategies for increasing crop productivity and yield and ensuring global food security.

Salt stress adversely impacts plants by hindering seed germination, growth and development, and flowering and fruiting [8,9]. The high concentrations of sodium in saline soil limits water uptake and the absorption of nutrients in the plant [10]. Water deficiency and nutritional imbalance induce primary stresses, including osmotic stress and ionic stress. These primary stresses result in oxidative stress and can cause a series of secondary stresses [11]. Together, salt stress leads to various physiological and molecular changes and impedes plant growth by inhibiting photosynthesis, thus reducing the available resources and repressing cell division and expansion [12]. Salt stress affects light-harvesting complex formation and regulates the state transition of photosynthesis [13]. Importantly, the enzyme 
activities or protein stabilities of the key enzymes in photosynthesis, such as ribulose-1,5bisphophate carboxylase/oxygenase (RuBisCO), are affected through modulating the glycation under salt stress condition. Salt stress also influences sugar signaling and alters the levels of sugars, such as sucrose, fructose, and glycolysis [14].

As sessile organisms, plants have to develop various strategies to adapt to saline environments. These strategies include a series of signaling transduction pathways that are involved in activities ranging from salt stress sensing to the expression of many salt-stressresponsive genes, which regulate processes including ion transport, osmotic homeostasis, and detoxification. These mechanisms rely on multiple regulatory elements, such as phytohormones, lipids, the cell wall, and the cytoskeleton [10-12].

This review briefly describes the recent progress in our understanding of salt stress responses and the underlying regulatory mechanisms in plants, focusing on salt stress signal sensing and transduction. Understanding the molecular mechanisms of plant salt stress regulation will provide insight on how to improve plant salt stress resistance and is a critical step in improving agricultural productivity and food security.

\section{Salt Stress Sensing}

The sensing of salt stress signals initiates a wide array of complex transduction pathways in plants. Early signals that trigger a salt stress response include excess $\mathrm{Na}^{+}$, the alteration of intracellular $\mathrm{Ca}^{2+}$ levels, and the accumulation of reactive oxygen species (ROS) [4]. Under salt stress, excess $\mathrm{Na}^{+}$is perceived rapidly and triggers downstream sodium stress responses [10] (Figure 1). Salt stress induces ion and osmotic stress, which leads to the elevation of $\mathrm{Ca}^{2+}$ in the cytosol; thus, salt stress and changes in osmotic pressure are always associated with the activation of $\mathrm{Ca}^{2+}$ channels. $\mathrm{Ca}^{2+}$ functions as an important secondary messenger by binding to and activating $\mathrm{Ca}^{2+}$ sensors, which evoke a specific calcium signal cascade. The plasma membrane calcium-permeable channel OSCA1 was identified as a putative osmosensor that is required for osmotic stress-induced $\mathrm{Ca}^{2+}$ signaling $[15,16]$. Under osmotic stress, the loss-of-function mutant osca1 displays impaired $\mathrm{Ca}^{2+}$ signal enhancement. The plastidial $\mathrm{K}^{+}$exchange antiporters KEA1/2 and KEA3 also act as an osmosensory component that participates in osmotic stress-induced $\mathrm{Ca}^{2+}$ elevation [17]. The Arabidopsis monocation-induced $\mathrm{Ca}^{2+}$ increases 1 (MOCA1) was identified as a $\mathrm{Na}^{+}$-gated calcium-permeable channel and participates in ionic stress-induced $\mathrm{Ca}^{2+}$ signaling [18]. The mocal mutant is hypersensitive to salt stress and lacks $\mathrm{Na}^{+}$-evoked $\mathrm{Ca}^{2+}$ enhancement. MOCA1 encodes a glucuronosyltransferase and functions in the biosynthesis of glycosyl inositol phosphorylceramide (GIPC). GIPCs are monovalent-cation sensors that sense $\mathrm{Na}^{+}$and regulate salt stress responses through activating MOCA1 to increase the $\mathrm{Ca}^{2+}$ influx [18]. The plasma membrane receptor-like kinase FERONIA (FER) was reported to be required for salt-induced $\mathrm{Ca}^{2+}$ spikes and waves to maintain cell wall integrity during salt stress [19]. FER interacts with the pectin component of the cell wall and can sense salt-stress-induced cell wall damage. Cyclic nucleotide-gated ion channels (CNGCs) are calcium-permeable channels that are inhibited by cellular calcium concentrations and are regulated by calmodulin (CaM). Together with BAK1, FER regulates calcium signaling by phosphorylating CNGCs $[20,21]$. Lastly, salt stress triggers the excessive accumulation of ROS, which also plays a key role in activating calcium signaling. The leucine-rich-repeat receptor kinase, hydrogen-peroxide-induced $\mathrm{Ca}^{2+}$ increases 1 (HPCA1), is a hydrogen peroxide sensor that is located in the plasma membrane that detects the increase of $\mathrm{H}_{2} \mathrm{O}_{2}$ under stress stimuli [22]. HPCA1 is required for stomatal closure by mediating the $\mathrm{H}_{2} \mathrm{O}_{2}$-triggered influx of $\mathrm{Ca}^{2+}[22]$. 


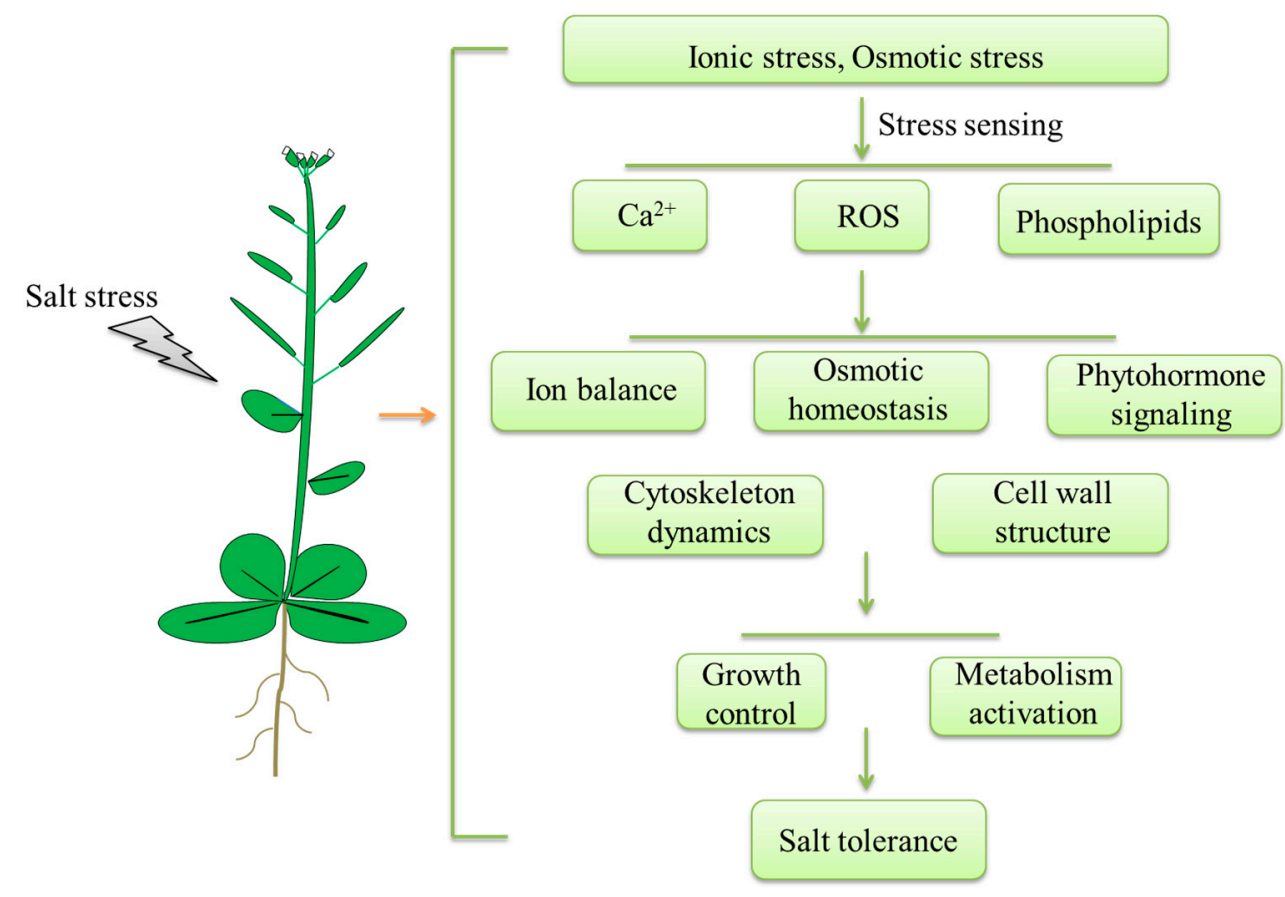

Figure 1. A simplified model of the plant salt stress response. Salt stress primarily causes ionic stress and osmotic stress. After sensing $\mathrm{Na}^{+}$and hyperosmolality, plants accumulate $\mathrm{Ca}^{2+}$, activate ROS signaling, and alter their phospholipid composition. These signals activate adaptive processes to alleviate salt stress, including maintaining an ion balance and osmotic homeostasis, inducing phytohormone signaling and regulating cytoskeleton dynamics and the cell wall structure. Subsequently, through an array of signal transduction pathways, plant growth is slowed and metabolism is activated to increase salt tolerance.

\section{Regulation of Plant Response to Salt Stress}

\subsection{Ion Balance}

Under salt stress, high concentrations of the sodium ion, $\mathrm{Na}^{+}$, accumulate in plant cells, ultimately to toxic levels, leading to the disruption of ion homeostasis [4,7]. Plants have developed systems to maintain low levels of $\mathrm{Na}^{+}$by removing $\mathrm{Na}^{+}$from the cytoplasm. This is mainly achieved using $\mathrm{Na}^{+} / \mathrm{H}^{+}$antiporters, which transport $\mathrm{Na}^{+}$in exchange for $\mathrm{H}^{+}$[11]. The plasma-membrane-localized $\mathrm{Na}^{+} / \mathrm{H}^{+}$antiporters transport $\mathrm{Na}^{+}$to the apoplast, and the vacuole-localized $\mathrm{Na}^{+} / \mathrm{H}^{+}$antiporters are responsible for maintaining $\mathrm{Na}^{+}$compartmentation in vacuoles. The salt overly sensitive (SOS) regulatory pathway regulates ion homeostasis through modulating $\mathrm{Na}^{+} / \mathrm{H}^{+}$antiporters activity during salt stress [4] (Figure 2).

After being triggered by cytoplasmic $\mathrm{Ca}^{2+}$, the SOS pathway functions to alleviate salt stress by exporting excess $\mathrm{Na}^{+}$. The $\mathrm{SOS}$ pathway is comprised of the $\mathrm{Na}^{+} / \mathrm{H}^{+}$antiporter SOS1, the protein kinase SOS2, and two calcium sensors, SOS3 and SCaBP8 (SOS3-like calcium-binding protein 8) [8]. Under salt stress, SOS3/SCaBP8 perceives the increased cytoplasmic calcium signal and transduces it to the downstream serine/threonine protein kinase, SOS2. SOS3/SCaBP8 recruits SOS2 to the plasma membrane and activates it. Subsequently, SOS2 phosphorylates SOS1, which enhances the plant salt tolerance by increasing the $\mathrm{Na}^{+} / \mathrm{H}^{+}$exchange activity [12]. SOS1 plays a key role in transporting $\mathrm{Na}^{+}$ from the cytoplasm to the apoplast. The efflux of $\mathrm{Na}^{+}$is driven by the proton gradient that is generated from the plasma membrane $\mathrm{H}^{+}$-ATPase. Under salt stress, SOS3/SCaBP8-SOS2 also regulates the activities of other transporters involved in ion homeostasis. For instance, the $\mathrm{K}^{+}$and $\mathrm{Na}^{+}$transporters, vacuolar $\mathrm{Na}^{+} / \mathrm{H}^{+}$exchanger (NHX), vacuolar $\mathrm{H}^{+}$-ATPases, and pyrophosphatases (PPase) were reported to be regulated by the SOS pathway [10]. 
In summary, the SOS pathway maintains the $\mathrm{Na}^{+}$homeostasis and transports excess $\mathrm{Na}^{+}$ from the cytosol to the apoplast to prevent the accumulation of $\mathrm{Na}^{+}$to toxic levels.

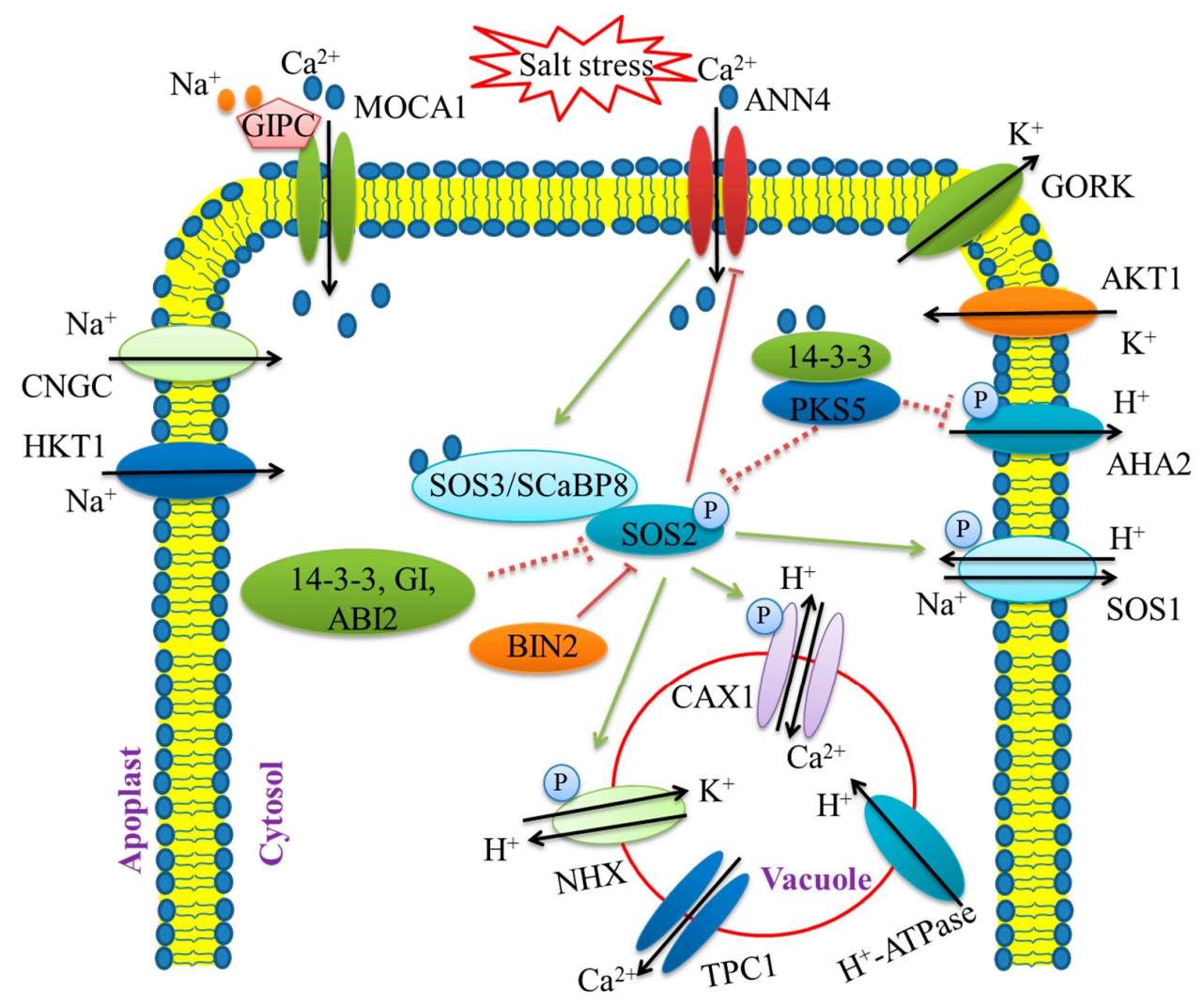

Figure 2. Salt stress triggers ion transport regulation in plant cells. Salt stress induces the accumulation of $\mathrm{Na}^{+}$and $\mathrm{Ca}^{2+}$ within the cell. The glucuronosyltransferase monocation-induced $\mathrm{Ca}^{2+}$ increases 1 (MOCA1) is as a Ca ${ }^{2+}$-permeable channel in the plasma membrane. Glycosyl inositol phosphorylceramide (GIPC) sphingolipids sense and bind to $\mathrm{Na}^{+}$to activate the MOCA1-mediated $\mathrm{Ca}^{2+}$ influx. The cyclic nucleotide-gated ion channel (CNGC) and high-affinity potassium $\left(\mathrm{K}^{+}\right)$transporter $(\mathrm{HKT1})$ are required for $\mathrm{Na}^{+}$transport into the cell. The inward-rectifier $\mathrm{K}^{+}$channel Arabidopsis $\mathrm{K}^{+}$ transporter (AKT1) and the outward-rectifier $\mathrm{K}^{+}$channel guard cell outward-rectifier $\mathrm{K}^{+}$channel (GORK) help to maintain the $\mathrm{Na}^{+} / \mathrm{K}^{+}$balance. The salt overly sensitive (SOS) pathway plays essential roles in $\mathrm{Na}^{+}$exclusion. The calcium sensor, SOS3/SCaBP8, recruits SOS2 to the plasma membrane and promotes SOS2-mediated phosphorylation of the $\mathrm{Na}^{+} / \mathrm{H}^{+}$ antiporter SOS1. Under normal conditions, the kinase SOS2 is repressed by 14-3-3, ABA insensitive 2 (ABI2), and GIGANTEA (GI). Additionally, SOS2-like protein kinase 5 (PKS5) phosphorylates and inhibits SOS2. Under salt stress conditions, 14-3-3 and GI are degraded and release SOS2 to phosphorylate SOS1. Then, 14-3-3 represses PKS5, thereby activating SOS2. Under salt stress conditions, the glycogen synthase kinase 3 (GSK3) kinase, brassinosteroid insensitive 2 (BIN2) fine-tunes the SOS2 activity to prevent overactivation. As a putative $\mathrm{Ca}^{2+}$-permeable transporter, the ANNEXIN protein member, ANN4, interacts with SCaBP8 and SOS2 and regulates calcium signaling under salt stress. During salt stress, SOS2 activates the vacuolar $\mathrm{H}^{+} / \mathrm{Ca}^{2+}$ antiporter CAX1 to promote $\mathrm{Ca}^{2+}$ enhancement and regulates the vacuolar $\mathrm{K}^{+} / \mathrm{H}^{+}$exchanger $\mathrm{NHX}$ to maintain the $\mathrm{K}^{+}$balance. The arrows and bars indicate positive and negative regulation, respectively. Solid lines and dashed lines indicate direct regulation and indirect regulation, respectively.

How the SOS pathway is regulated has been thoroughly investigated. The kinase activity of SOS2 is specifically activated by salt stress stimuli. Under normal conditions, several protein factors inhibit the SOS2 activity and the SOS pathway, such as SOS2like protein kinase 5 (PKS5), the phosphatase ABA (abscisic acid) insensitive 2 (ABI2), 14-3-3, and GIGANTEA (GI). PKS5 inhibits SOS2 kinase activity via phosphorylation at Ser294 of SOS2. The 14-3-3 protein functions as a protein-kinase-interacting partner of SOS2 at phosphorylated Ser294 and inhibits the kinase activity of SOS2. Interestingly, 14-3-3 proteins also function as a negative regulator of PKS5. Salt stress promotes the 
interaction between 14-3-3 proteins and PKS5, causing the inhibition of SOS2 and $\mathrm{H}^{+}-$ ATPase activity [23]. During this process, 14-3-3 proteins bind to $\mathrm{Ca}^{2+}$ and are directly modulated by the $\mathrm{Ca}^{2+}$ signal. Under non-stress conditions, GI also inhibits SOS2. In response to salt stress, both 14-3-3 and GI are degraded, thereby releasing SOS2 to activate the downstream protein kinase cascade [24-26]. In addition, geminivirus RER-interacting kinase 1 (GRIK1) activates SOS2 by mediating the phosphorylation of SOS2 on Thr168 [27]. The calcium-dependent membrane-binding protein, ANNEXIN4 (ANN4), interacts with the SOS2/SCaBP8 complex to fine-tune calcium signaling under salt stress [28]. Besides these activating mechanisms, the SOS pathway deactivates the regulatory system. Once the salt stress is removed, BIN2, a glycogen synthase kinase 3 (GSK3)-like kinase that is the central component in brassinosteroid (BR) signaling, phosphorylates SOS2 on the Thr172 residue to inhibit SOS2 activity and promotes plant growth via BES1/BZR1-mediated transcriptional networks [29].

Under salt stress, plants have to modulate the $\mathrm{Na}^{+} / \mathrm{K}^{+}$homeostasis through maintaining high $\mathrm{K}^{+} / \mathrm{Na}^{+}$ratio since excessive $\mathrm{Na}^{+}$often leads to $\mathrm{K}^{+}$deficiency $[4,12]$. The sos mutants show impaired $\mathrm{Na}^{+} / \mathrm{K}^{+}$homeostasis during salt stress. The uptake of $\mathrm{K}^{+}$is inhibited in $\mathrm{SCaBP} 8$ mutants under salt stress [30]. The potassium transporters, along with voltage-gated channel proteins and their regulators, play important roles in mediating $\mathrm{K}^{+}$ absorption, release, and transportation at the cellular and whole-plant levels. For instance, the inward-rectifier $\mathrm{K}^{+}$channel Arabidopsis $\mathrm{K}$ transporter (AKT1) is a major contributor to $\mathrm{K}^{+}$uptake and transport. Salt stress inhibits the activity of AKT1 [31]. The calcineurin B-like (CBL) proteins and CBL-interacting protein kinases (CIPKs) interact with and activate AKT1. CIPK23 phosphorylates and activates AKT1 to increase $\mathrm{K}^{+}$uptake under $\mathrm{K}^{+}$-deficient conditions $[32,33]$. Two CBL proteins, CBL1 and CBL9, activate the phosphorylation of CIPK23 on AKT1 to ensure the activity enhancement of AKT1 [34]. However, CBL10 competes with CIPK23 for binding to AKT1 and negatively modulates AKT1 activity [30]. A protein phosphatase $2 \mathrm{C}$ (PP2C) member, AIP1, mediates the dephosphorylation of AKT1 and negatively regulates CIPK23-activated AKT1 [35,36]. Tonoplast-localized $\mathrm{K}^{+}$ channel (TPK1) is regulated by salt stress and modulates the cytosolic $\mathrm{K}^{+}$influx during salinity stress [37]. Salt stress triggers calcium-dependent protein kinase (CDPK) to phosphorylate TPK1 and activate the $\mathrm{K}^{+}$influx [38]. High-affinity potassium transporter, HKT1, provides sodium exclusion and the maintenance of high $\mathrm{K}^{+} / \mathrm{Na}^{+}$in leaves during salinity stress [39]. Previous studies have indicated that the maintenance of a low $\mathrm{Na}^{+}$concentration in leaves is an essential strategy for plants to enhance their salt tolerance $[40,41]$. HKT1 mediates low-affinity $\mathrm{Na}^{+}$transport and plays a role in the distribution of $\mathrm{Na}^{+}$from the root-to-shoot xylem sap. ZmHKT1 causes leaf $\mathrm{Na}^{+}$exclusion promotion and is identified as a major salt-tolerance quantitative trait locus (QTL) [42]. HKT1 physically interacts with phosphatase PP2C49, which then inhibits the $\mathrm{Na}^{+}$permeability of HKT1 and negatively regulates salt tolerance [43]. The salt stress response is regulated by the circadian clock in plants. Several proteins that maintain the circadian clock play key roles in regulating salt stress tolerance $[44,45]$. Recently, studies have demonstrated a new molecular link between clock components and salt stress tolerance in rice. Oryza sativa pseudo-response regulator (OsPRR73) is induced by salt and specifically confers salt tolerance by recruiting HDAC10 to transcriptionally repress OsHKT2;1 and, therefore, regulates rice salt tolerance [46]. Membrane compartment-localized aquaporins might also participate in ion balance regulation through controlling root water uptake, leaf water transpiration, stomatal closure, and small molecule transport in response to salt stress. For instance, the overexpression of the wheat aquaporin TdPIP2;1 improves salt stress tolerance through retaining a low $\mathrm{Na}^{+} / \mathrm{K}^{+}$ ratio under high-salt-stress conditions [47].

\subsection{Osmotic Homeostasis}

Under salt stress, ion imbalance and water deficiency in the plant cell cause osmotic stress. This results in multiple transient biophysical changes, such as the reduction in cell turgor pressure, shrinkage of the plasma membrane, and physical alteration of the 
cell wall [4]. To alleviate osmotic stress, plants rely on osmotic signaling pathways that regulate processes ranging from gene expression and activation of osmolyte biosynthesis enzymes to water transport systems [41]. Osmolytes, such as proline, polyols, and sugars, accumulate under salt stress. These osmolytes participate in the regulation of osmotic pressure by lowering the osmotic potential in the cytosolic compartment. They also act as signaling molecules to induce ABA accumulation, affect related gene expression, and regulate plant growth under salt stress [48]. Protein kinases act as a convergence point of rapid osmoregulation and salt stress signaling [49]. In response to osmotic treatments, the mRNA levels of histidine kinases, MAPKKK, MAPKK, and MAPK are increased, leading to increased osmolyte synthesis and accumulation [50,51]. Numerous studies have suggested the mitogen-activated protein kinases (MAPKs) are involved in ROS homeostasis [52,53]. For example, ZmMPKs are induced by salt stress and activate oxidative stress regulation to confer salt stress tolerance [51-53]. The receptor-like kinase, salt intolerance 1, is activated by MPK3 and MPK6 and functions in the salt-stress-induced oxidative stress response [54]. Osmotic and salt stresses both induce a rapid increase in cytosolic $\mathrm{Ca}^{2+}$. The copine protein, $\mathrm{Ca}^{2+}$-responsive phospholipid-binding BONZAI1 (BON1), is a critical upstream regulator of osmotic stress signaling since it positively regulates calcium signaling [55]. The disruption of BON1 dampens the cytosolic $\mathrm{Ca}^{2+}$ signal in response to osmotic stress.

In plants, salt-stress-triggered ion stress and osmotic stress cause a metabolism imbalance and the toxic accumulation of ROS, inducing plant oxidative damage [40]. Under salt stress, ROS are produced in many plant organelles, such as chloroplast, peroxisomes, mitochondria, and the apoplast. Plant cells sense the accumulated ROS and respond using rapid regulatory mechanisms to scavenge ROS and activate a series of downstream adaptive responses $[4,11,12]$. ROS function as essential signaling molecules at low levels. Thus, strict control mechanisms are used to balance ROS production and scavenging. Under salt stress, several proteins were found to participate in oxidative stress regulation by activating ROS scavengers or mediating the gene expression of ROS-responsive genes [56]. Several studies have shown that the activities of ROS scavenging enzymes and antioxidants are triggered by salt stress stimuli [57]. For example, the ascorbates peroxidase and catalase are activated by salt stress, improving the tolerance to salinity and oxidative stresses [58]. The overexpression of the ascorbate peroxidases, OsAPXa or OsAPXb, enhances the salt tolerance in rice [59]. Similarly, the constitutive expression of OsGSTU4 (glutathione S-transferase) in Arabidopsis also increases the tolerance to salt stress [60]. In rice, the MADS-box transcription factor, OsMADS25, is required for salt tolerance because of its role in maintaining ROS homeostasis [61]. Senescence-associated genes (SAGs) are involved in detoxification in response to salt stress stimuli [62]. The loss of function of SAG29 renders plant seedlings insensitive to salt treatment, while the overexpression of SAG29 results in high sensitivity to salt treatment in Arabidopsis. Studies show that NADPH oxidase, respiratory burst oxidase homolog gene, $\mathrm{RBOH}$, mediates ROS synthesis and ROS scavenging to modulate plant development and stress responses [63].

\subsection{Phytohormone Signaling Mediation-ABA Signaling and BR Signaling}

To withstand constantly changing stress conditions in the environment, plants have developed phytohormone-mediated stress resistance mechanisms. Phytohormones play a crucial role in the plant response to salt stress by regulating plant growth and development adaptation. Phytohormones make great contributions to salt stress signal perception and defense system mediation. Nine plant hormones have been well characterized and are divided into two groups: growth promotion hormones and stress response hormones [64]. The growth promotion hormones are composed of auxin, gibberellin (GA), cytokinins (CKs), brassinosteroids (BRs), and strigolactones (SLs). Some of the growth promotion hormones can also play a role in stress response, such as SLs and BRs [64]. The stress response hormones contain abscisic acid (ABA), ethylene, salicylic acid (SA), and jasmonic acid (JA). The crosstalk between different phytohormones also is important for the salt stress response. 
Among the nine plant phytohormones, $\mathrm{ABA}$ is the most important hormone regulating stress responses. $\mathrm{ABA}$ functions as an important secondary signaling molecule to activate a kinase cascade and mediate gene expression during the salt stress response (Figure 3). Under stress conditions, ABA synthesis is induced quickly leading to rapid increases in ABA levels [65]. A high level of ABA activates kinase cascades and improves stress recognition and stress defense reactions [66]. Salt stress limits water uptake, leading to cell dehydration and changes in cell turgor, generating osmotic stresses. Under high-salinity conditions, the increase in endogenous ABA levels causes stomatal closure to regulate water balance and osmotic homeostasis [67]. Thus, osmoregulation is an important function of the ABA-mediated plant salt stress response.

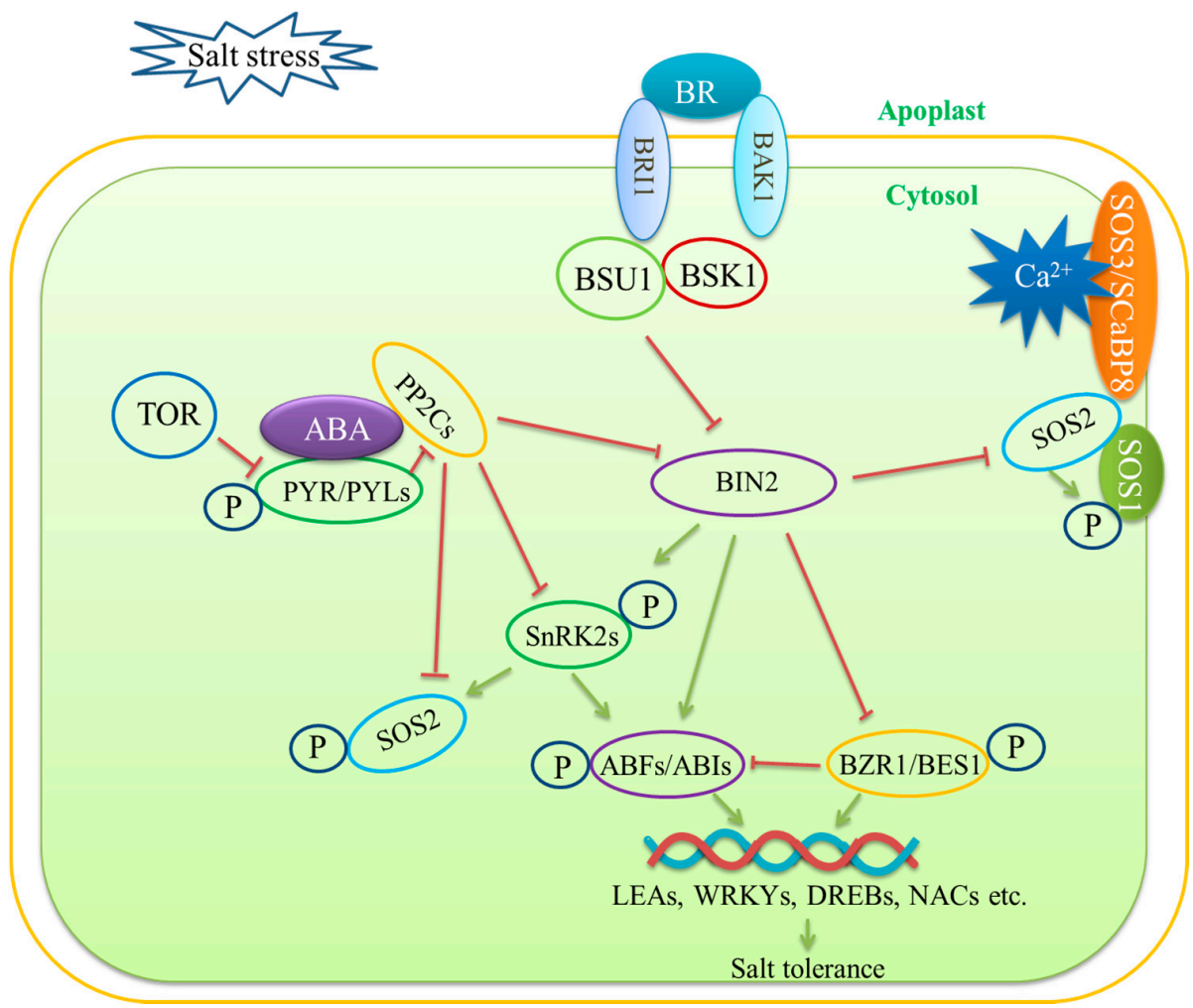

Figure 3. ABA and BR signaling during salt stress. Salt stress promotes abscisic acid (ABA) accumulation. The sucrose nonfermenting-1-related protein kinase2s (SnRK2s) and the clade A type 2C protein phosphatases (PP2Cs) play key roles in mediating the crosstalk between ABA and salt stress signaling. The ABA receptors, PYRABACTIN RESISTANCE/PYR-LIKE (PYR/PYLs) sense ABA and repress PP2Cs, thereby activating the downstream kinase SnRK2. SnRK2s phosphorylate the transcription factors ABSCISIC ACID RESPONSIVE ELEMENT-BINDING FACTORs (ABFs) and ABIs to regulate the expression of stress-responsive genes. The target of rapamycin (TOR) phosphorylates PYL and represses ABA signaling and stress responses. ABI2, a member of the PP2Cs, binds to SOS2 to inhibit its kinase activity, thereby negatively regulating salt tolerance. Additionally, under salt stress, SnRKs phosphorylate SOS2 to activate osmoregulation. Salt stress also upregulates BR biosynthesis. The membrane receptor brassinosteroid insensitive 1 (BRI1) senses BR molecules and acts with its coreceptor BRI1-associated receptor kinase 1 (BAK1) to initiate the downstream phosphorylation cascade. BRI1 and BAK1 transduce the BR signal to BR signaling kinase 1 (BSK1) and activate BRI1 suppressor 1 (BSU1). BSU1 inhibits BIN2 and promotes the transcription factors BZR1/BES1 to induce the expression of BR-responsive genes, which enhances salt tolerance. Under salt stress, BIN2 phosphorylates and inhibits SOS2. This phosphoregulation by BIN2 prevents SOS2 overactivation. Arrows and bars indicate positive and negative regulation, respectively. Solid lines and dashed lines indicate direct regulation and indirect regulation, respectively. 
ABA is a 15-carbon isoprenoid that is produced from the methylerythritol 4-phosphate (MEP) pathway via the cleavage of carotenoids. Several enzymes play key roles in the regulation of ABA biosynthesis, such as zeaxanthin oxidase (ZEP), 9-cis-epoxycarotenoid (NCED), and short-chain alcohol dehydrogenase (SCAD) [68]. NCEDs catalyze the ratelimiting carotenoid cleavage reaction. NCED5 plays an essential role in ABA synthesis and is rapidly induced under salt stress conditions in rice [69]. The small peptide CLAVATA3/ESR-RELATED 25 (CLE25) is secreted from the roots and modulates stomatal control via ABA in root-to-shoot long-distance signaling. The root-derived CLE25 is perceived by the BARELY ANY MERISTEM (BAM) receptors, BAM1 and BAM3, and promotes ABA biosynthesis by upregulating the NCED3 expression in Arabidopsis [70]. $\mathrm{ABA}$ is primarily synthesized in the root system. ABA is first synthesized in plastids in the root tips and then transported to the shoot and leaves. Changes in ABA levels in roots and leaves have been detected in high-salinity conditions. Arabidopsis ABA1, which encodes zeathanxin epoxidase, is the key regulator of ABA synthesis and is also induced by salt stress [71]. Under salt stress, ABA-deficient mutants perform poorly and show salt sensitivity.

Salt-stress-induced osmotic stress also activates ABA signaling transduction pathways. The sucrose-nonfermenting-1-related protein kinase 2s (SnRK2s) are the central components in ABA signaling pathways and play critical roles in osmoregulation [72]. The kinase activities of SnRK2.2/3/6 are inhibited by protein phosphatase 2Cs (PP2Cs) in the absence of $\mathrm{ABA}$. Upon osmotic stress, the ABA receptor proteins, including pyrabactin resistance 1 (PYR1), PYR1-like (PYL), and regulatory component of ABA receptors (RCAR), perceive and bind to the accumulated ABA, which subsequently suppresses the phosphatase activity of PP2Cs [66,72]. As a result, in the absence of inhibition by PP2Cs, SnRK2s are quickly activated. After stress removal, PYL is phosphorylated by the target of rapamycin (TOR) kinase and then disassociates from ABA or PP2C, leading to inactivation of the stress response to promote growth recovery [73]. Recent studies suggest that the upstream kinases, namely, the B2, B3, and B4 Raf-like kinases, are quickly activated and are required for the phosphorylation and activation of $\mathrm{SnRK} 2 \mathrm{~s}$ in response to early osmotic stress [74]. The Raf-like protein kinases and SnRK2s form the protein kinase cascade that is activated during early osmotic regulation in response to salt stress. The phosphatase ABI1 (abscisic acid insensitive 1) and okadaic acid-sensitive phosphatases of the phosphoprotein phosphatase (PPP) family inhibit the kinase activity of salt-stress-activated SnRK2.4 and regulate primary root growth during the salt stress response [75].

ABA levels increase rapidly under salt stress. Subsequently, salt-stress-induced $\mathrm{ABA}$ signaling upregulates the expression of many genes via the targeting of ABAresponsive elements (ABREs) in the regulatory regions of their promoter [76]. ABREbinding protein/ABRE-binding factor (AREB/ABF) transcription factors are master transcription factors that cooperatively regulate the ABRE-mediated transcription of downstream target genes, enhancing salt stress tolerance. SnRK2s phosphorylate and positively control the AREB/ABF transcription factors [77]. Moreover, the SOS pathway coordinates with ABA signaling. The phosphatase ABI2 (abscisic acid insensitive 2) binds to SOS2 and mediates SOS2 inhibition [78].

Brassinosteroids (BRs) are steroidal hormones that mediate various physiological processes, including cell growth and development, flowering and fruiting [79], and plant stress tolerance. Under salt stress, the biosynthesis of BRs is increased to enhance plant stress tolerance by maintaining ion homeostasis and via osmoregulation. Exogenous BR application reduces ROS production, enhances osmotic regulation and ionic homeostasis, induces the expression of stress-responsive genes, and causes translational changes in stress-responsive proteins. In Malus hupehensis, exogenous BR application regulates the activity of $\mathrm{Na}^{+} / \mathrm{H}^{+}$antiporters and NHX and alleviates salt stress. Exogenous applications of BRs reduce cytosolic $\mathrm{Na}^{+}$levels and increase the absorption of $\mathrm{K}^{+}$, which is concomitant with higher salt tolerance [80]. Application with 24-epibrassinolide (EBL), a byproduct from the brassinolide biosynthetic pathway, promotes plant growth and development 
under salt stress [81]. The overexpression of BR-INSENSITIVE 1 (BRI1)-LIKE receptor homolog 3 (BRL3) promotes the accumulation of osmolytes, such as proline and sugars, which play roles in osmoregulation under salt stress $[82,83]$. The genetic and phenotypic results of BR-related mutants and overexpression transgenic plants indicate that a proper enhancement of BR signaling benefits plants' defense against salt stress [83]. The tomato BZR homolog gene, SIBZR1, positively regulates salt tolerance in tomatoes and upregulates the expression of multiple stress-related genes [84]. The BR receptor SERK2 significantly enhances grain size and salt resistance in rice. Adverse high salinity conditions induce SERK2 accumulation to enhance early BR signaling on the plasma membrane to defend against the stress [85].

Under salt stress, BR exerts anti-stress effects by interacting with other hormones, such as $A B A$. ABA inhibits the growth-promoting effects of BR during salt stress (Figure 3). ABA and BRs antagonistically fine-tune plant growth under salt stress. The BR receptor BAK1 regulates SnRK2.6 and modulates stomatal closure [86]. BIN2 indirectly activates ABI5, the key transcription factor in the ABA signaling pathway, by phosphorylating SnRK2.6 [87,88]. Brassinazole-resistant 1 (BZR1) and BRI1-EMS-suppressor 1 (BES1) are transcription factors that have been elucidated largely in the BR signaling pathway. BZR1 and BZR2 directly inhibit ABI5 expression [89]. BR shares transcriptional targets with ABA, suggesting that $\mathrm{BR}$ antagonistically acts with $\mathrm{ABA}$ to regulate the stress response.

The BR pathway can also crosstalk with the SOS pathway. BRs induce the accumulation of calcium in the cytosol, which in turn activates the SOS pathway to regulate ionic and osmotic stresses $[81,90]$. A recent study has reported that BIN2 inhibits SOS2 kinase activity and negatively regulates salt stress tolerance as a molecular switch in the transition to robust growth after salt stress [29].

\subsection{Cytoskeleton Functions}

The cytoskeleton plays important roles in a wide variety of cellular processes, including cell shape determination, cell movement, vesicle trafficking, tip growth, and responses to external stress stimuli [91]. The plant cytoskeleton consists of actin filaments (F-actin) and microtubules (MTs), which constantly undergo dynamic changes in architecture. The cytoskeleton has important functions in the plant salt stress response and helps plants to withstand stress conditions through dynamic organizational changes [41]. Cytoskeletonassociated proteins, including MT-associated proteins (MAPs) and actin-binding proteins (ABPs), bind to the cytoskeleton and regulate cytoskeleton organization. Microtubuleassociated protein 65-1 (MAP65-1) regulates microtubule stabilization in response to salt stress. Phosphatidic acid (PA) directly binds to MAP65-1 to modulate its microtubule activity [92].

Salt stress triggers changes in the cytoskeleton architecture by modulating dynamic events, such as nucleation and polymerization, severing and depolymerizing, crosslinking/bundling, and growth/shrinkage [93]. During salt stress, the cortical microtubules are first depolymerized and then reorganized. The destabilization of cortical microtubules enhances salt stress tolerances in plants [94,95]. Similarly, actin depolymerization and stabilization are important for plant salt tolerance. The SOS pathway regulates actin dynamics in response to salt stress. Several studies have provided ample pharmacological evidence to link the SOS pathway to cytoskeleton organization [96-98]. The sos mutants show abnormal responses to microtubule-associated drugs [99]. The addition of the microtubule-disrupting drug, Oryzalin, causes more death in the sos1 mutant. Actin reorganization in sos mutants is also abnormal in response to salt stress. Disruption of the actin filaments with actinfilament-disrupting drugs, latrunculin A and cytochalasin D (CD), increases death in sos2 seedlings under salt treatment conditions, while the stabilization of actin filaments with the actin filament stabilizing drug, phalloidin, rescues the lethality phenotype [100].

Calcium is a central secondary messenger that plays an important role in plant salt tolerance. Salt stress induces calcium accumulation in the cytosol and triggers calcium signaling transduction. The cytoskeleton is an important upstream and downstream 
regulator of calcium signaling [101]. Salt-stress-induced depolymerization of the cortical microtubules leads to the release of $\mathrm{Ca}^{2+}$ in the cytosol. The subsequent reorganization of microtubules during salt stress regulates the calcium influx to improve the plant's salt tolerance. Actin dynamics play a role upstream of $\mathrm{Ca}^{2+}$ signaling and serve as a signal to induce $\mathrm{Ca}^{2+}$ accumulation. Under salt stress, changes in cytoskeleton organization act as a transducer to activate calcium signaling. The actin-related protein2/3 (Arp2/3) complex, as the actin nucleation factor, functions in actin-dynamics-mediated calcium elevation under salt stress [102]. The Arp2/3 complex regulates mitochondrial-dependent $\mathrm{Ca}^{2+}$ stimulation via the regulation of the integrity of mitochondria, which is an important organelle for calcium release in response to salt stress. The actin cytoskeleton also plays a role in decoding the downstream calcium signal. The SOS pathway, which is activated by calcium under salt stress, is closely tied to actin dynamics. SOS3, which serves as a calcium sensor in plants, was reported to play a role in regulating actin dynamics under salt stress. The loss of function in SOS3 leads to an abnormal arrangement of actin filaments in response to salt stress, which can be rescued with external calcium application.

Actin dynamics are also important for ROS production under salt stress. Disordered actin organization triggers an accumulation of ROS levels in the Arabidopsis root and acts as the initial signal to activate the salt stress response [96].

\subsection{Cell Wall Regulation}

Accumulating evidence has demonstrated that the cell wall plays an indispensable role in the plant response to salt stress [103]. Salt stress inhibits plant growth and development by repressing cell expansion and division. The cell wall is an important factor for determining cell shape and function and is the first layer of defense against salt stress [12]. Salt stress induces water deficiency in plant cells, causing changes in cell turgor pressure. The cell wall provides mechanical strength to withstand these cell turgor changes [104].

It is believed that the cell wall is one of the early sensors of salt stress. The stress signal is perceived by cell wall sensors localized on the plasma membrane, leading to the induction of downstream responses. One of these cell wall sensors is FER, which is a receptor-like kinase with binding activity to RALF (RAPID ALKALINIZATION FACTOR) peptides [105]. FER senses salt-induced cell wall changes and, in return, sends a downstream signal of cell wall integrity damage. Cell wall leucine-rich repeat extensins (LRX) 3/4/5 function together with RALF peptides and FER to regulate plant growth under salt stress through the modulation of cell wall changes [106].

The cell wall is composed of a complex network of polysaccharides, including cellulose, pectin, and lignin. Secondary cell walls consist of cellulose, hemicelluloses, lignin, and other plant biomass and are distributed in the xylem, fibers, and anther cells. The synthesis of cell wall components is regulated by complicated transcriptional mechanisms under salt stress [107]. The NAC domain and Homeobox HD-ZIP ClassIII (HD-ZIPIII) transcription factors are master regulators of secondary cell wall synthesis [108]. The transcription factors MYB46/MYB83 activates the secondary wall biosynthesis through a transcriptional regulatory program [109]. Cell wall synthesis is tightly regulated by phytohormones, particularly ABA. Both ABA synthesis and signaling are involved in secondary cell wall thickening and lignification [110,111]. SnRK2 kinases, namely, SnRK2.2, 2.3, and 2.6, regulate secondary wall biosynthesis by physically interacting with a NAC family transcription factor, namely NAC secondary wall thickening promoting factor 1 (NST1). SnRK2 phosphorylates NST1 at Ser316, which is a site that is required for the transcriptional activation of downstream secondary wall biosynthesis genes [112].

On the other hand, cell wall components, such as cellulose, lignin, and other polysaccharides, have important biological functions in the plant's response to salt stress $[110,113]$. Cellulose, the main component of the cell wall, is synthesized by cellulose synthase (CesA) complexes (CSC) at the plasma membrane and tracks along cortical microtubules at a steady pace guided by the protein cellulose synthase interacting (CSI) 1/POM2 [114]. A cellulose synthase-microtubule uncoupling $(\mathrm{CMU})$ protein has been found to affect 
the function of CSC. CMU is associated with the plasma membrane and interacts with microtubules to regulate cell expansion and development by modulating microtubule displacement [115]. Recent studies have reported that companion of cellulose synthesis (CC) proteins are required for the association of CSCs with microtubules. CC protein1 (CC1) is a MAP that regulates microtubule dynamics to sustain plant growth under salt stress [116]. The mutation of CESA6, CSI1/POM2, or CC1 confers enhanced sensitivity to salt stress in Arabidopsis [115-117]. Another cell wall component, namely, lignin, also plays roles in the plant's adaption to saline conditions. Under saline conditions, plant cells adapt to stress by accumulating lignin and thickening the cell wall. As the central component in lignin biosynthesis, caffeoyl-CoA O-methyltransferase 1 (CCoAOMT1) has been reported to play an essential role in the salt stress response [117]. The loss of function of CCoAOMT1 leads to high sensitivity to salt stress. A recent study showed that $\beta$-1,4-galactan, a cell wall component, has specific functions in salt hypersensitivity. The synthase GALACTAN SYNTHASE1 (GALS1) catalyzes the biosynthesis of $\beta-1,4$-galactan. Salt stress induces the expression of GALS1 and results in the accumulation of $\beta-1,4$-galactan levels in plants, which diminishes salt tolerance. This process is transcriptionally regulated. BARLEY B RECOMBINANT/BASIC PENTACYSTEINE transcription factors BPC1/BPC2 repress the expression of GALS1 and positively regulate plant salt tolerance [118].

\section{Conclusions}

Plants must efficiently adjust their growth to adapt to stress conditions. Salt stress is one of the most serious abiotic stresses experienced worldwide. Identifying the salt stress signaling pathway and characterizing the upstream salt stress sensors could guide approaches to mitigate the negative effects of salt stress on crop yields and ultimately improve agricultural development. Salt stress adversely affects plant growth and development, whereas plants have evolved regulatory mechanisms that allow them to adapt to these adverse conditions. For instance, plant growth is inhibited by salt stress due to decreased photosynthesis. However, the plant also actively slows the growth rate in response to salt stress, leading to increased survival. Plant cells undergo large changes to respond and defend against salt stress. For example, salt stress induces ion stress. In turn, plant cells activate ion transporters and channels to reestablish the ion balance. In the ion transport process, the $\mathrm{Na}^{+}$exclusion, $\mathrm{K}^{+}$influx, $\mathrm{Ca}^{2+}$ pump, and $\mathrm{Na}^{+} / \mathrm{H}^{+}$exchange are all important for plant salt tolerance. In addition, strategies for osmotic and oxidative stress alleviations are also utilized in plants under saline conditions. The identification of upstream regulators, the characterization of a high-resolution sensor, transporter, and channel of $\mathrm{Na}^{+}$and $\mathrm{K}^{+}$, and the identification of a novel channel and pool of $\mathrm{Ca}^{2+}$ will be areas of active future interest.

High throughput and efficient biotechnologies are important for salt-stress-related gene screening. To date, RNA sequencing has proven to be a fast and effective method for studying the molecular regulation of plant salt tolerance. Transcriptome sequencing techniques have been widely used to identify novel genes that are linked to the regulation of the plant salt stress response $[119,120]$. The development of next-generation sequencing technology has made it easier to screen for salt-tolerance genes [121,122]. The global survey of transcriptome profiles and microRNA levels of plants in response to salt stress using RNA-Seq has provided useful insights into the mechanisms of salt tolerance [123]. These findings also provide a rich resource for breeding salt-tolerant cultivars through biotechnological approaches using salt-related genes.

Author Contributions: S.Z., H.Z., and P.W. wrote this manuscript. Q.Z. and M.L. participated in the writing and modification of this manuscript. C.M. conceptualized the idea. All authors have read and agreed to the published version of the manuscript. 
Funding: This work was supported by the National Natural Science Foundation of China (31700222, 31870241); Shandong Provincial National Science Foundation, China (ZR2017BC026); China Postdoctoral Science Foundation (2017M610444); the Open Project of State Key Laboratory of Plant Physiology and Biochemistry (SKLPPBKF1704).

Institutional Review Board Statement: Not applicable.

Informed Consent Statement: Not applicable.

Data Availability Statement: Not applicable.

Conflicts of Interest: The authors declare no conflict of interest.

\section{References}

1. Savary, S.; Akter, S.; Almekinders, C.; Harris, J.; Korsten, L.; Rötter, R.; Waddington, S.; Watson, D. Mapping disruption and resilience mechanisms in food systems. Food Secur. 2020, 12, 695-717. [CrossRef]

2. Hazell, P.B.R.; Wood, S. Drivers of change in global agriculture. Philos. Trans. R. Soc. B Biol. Sci. 2007, 363, 495-515. [CrossRef]

3. Qadir, M.; Quillérou, E.; Nangia, V.; Murtaza, G.; Singh, M.; Thomas, R.J.; Drechsel, P.; Noble, A.D. Economics of salt-induced land degradation and restoration. Nat. Resour. Forum 2014, 38, 282-295. [CrossRef]

4. Park, H.J.; Kim, W.-Y.; Yun, A.D.-J. A New Insight of Salt Stress Signaling in Plant. Mol. Cells 2016, 39, 447-459. [CrossRef]

5. Ziska, L.H.; Bunce, J.A.; Shimono, H.; Gealy, D.R.; Baker, J.T.; Newton, P.C.D.; Reynolds, M.P.; Jagadish, K.S.V.; Zhu, C.; Howden, M.; et al. Food security and climate change: On the potential to adapt global crop production by active selection to rising atmospheric carbon dioxide. Proc. R. Soc. B Boil. Sci. 2012, 279, 4097-4105. [CrossRef]

6. Su, T.; Li, X.; Yang, M.; Shao, Q.; Zhao, Y.; Ma, C.; Wang, P. Autophagy: An Intracellular Degradation Pathway Regulating Plant Survival and Stress Response. Front. Plant Sci. 2020, 11, 164. [CrossRef]

7. Horie, T.; Karahara, I.; Katsuhara, M. Salinity tolerance mechanisms in glycophytes: An overview with the central focus on rice plants. Rice 2012, 5, 1-18. [CrossRef]

8. Quan, R.; Lin, H.; Mendoza, I.; Zhang, Y.; Cao, W.; Yang, Y.; Shang, M.; Chen, S.; Pardo, J.M.; Guo, Y. SCABP8/CBL10, a Putative Calcium Sensor, Interacts with the Protein Kinase SOS2 to Protect Arabidopsis Shoots from Salt Stress. Plant Cell 2007, 19, 1415-1431. [CrossRef] [PubMed]

9. Park, H.J.; Kim, W.-Y.; Yun, D.-J. A role for GIGANTEA. Plant Signal. Behav. 2013, 8, e24820. [CrossRef] [PubMed]

10. Gong, Z. Plant abiotic stress: New insights into the factors that activate and modulate plant responses. J. Integr. Plant Biol. 2021, 63, 429-430. [CrossRef] [PubMed]

11. Zhu, J.K. Salt and drought stress signal transduction in plants. Annu. Rev. Plant Biol. 2002, 53, 247-273. [CrossRef] [PubMed]

12. Van Zelm, E.; Zhang, Y.; Testerink, C. Salt Tolerance Mechanisms of Plants. Annu. Rev. Plant Biol. 2020, 71, 403-433. [CrossRef] [PubMed]

13. Chen, Y.; Hoehenwarter, W. Changes in the Phosphosproteome and Metabolome Link Early Signaling Events to Rearrangement of Photosynthesis and Central Metabolism in Salinity and Oxidative Stress Response in Arabidopsis. Plant Physiol. 2015, 69, 3021-3033. [CrossRef] [PubMed]

14. Shumilina, J.; Kusnetsova, A.; Tsarev, A.; Van Rensburg, H.C.J.; Medvedev, S.; Demidchik, V.; Ende, W.V.D.; Frolov, A. Glycation of Plant Proteins: Regulatory Roles and Interplay with Sugar Signalling? Int. J. Mol. Sci. 2019, 20, 2366. [CrossRef] [PubMed]

15. Yuan, F.; Yang, H.; Xue, Y.; Kong, D.; Ye, R.; Li, C.; Zhang, J.; Theprungsirikul, L.; Shrift, T.; Krichilsky, B.; et al. OSCA1 mediates osmotic-stress-evoked $\mathrm{Ca}^{2+}$ increases vital for osmosensing in Arabidopsis. Nat. Cell Biol. 2014, 514, 367-371. [CrossRef] [PubMed]

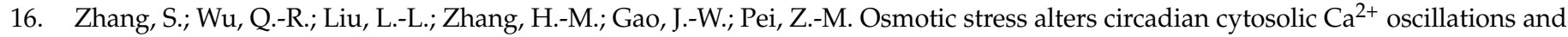
OSCA1 is required in circadian gated stress adaptation. Plant Signal. Behav. 2020, 15, 1836883. [CrossRef]

17. Stephan, A.B.; Kunz, H.H.; Yang, E.; Schroeder, J.I. Rapid hyperosmotic-induced Ca ${ }^{2+}$ responses in Arabidopsis thaliana exhibit sensory potentiation and invovlement of plastidial KEA transporters. Proc. Natl. Acad. Sci. USA 2016, 113, E5242-E5249. [CrossRef]

18. Jiang, Z.; Zhou, X.; Tao, M.; Yuan, F.; Liu, L.; Wu, F.; Wu, X.; Xiang, Y.; Niu, Y.; Liu, F.; et al. Plant cell-surface GIPC sphingolipids sense salt to trigger $\mathrm{Ca}^{2+}$ influx. Nat. Cell Biol. 2019, 572, 341-346. [CrossRef]

19. Feng, W.; Kita, D.; Peaucelle, A.; Cartwright, H.N.; Doan, V.; Duan, Q.; Liu, M.-C.; Maman, J.; Steinhorst, L.; Schmitz-Thom, I.; et al. The FERONIA Receptor Kinase Maintains Cell-Wall Integrity during Salt Stress through Ca ${ }^{2+}$ Signaling. Curr. Biol. 2018, 28, 666-675.e5. [CrossRef]

20. Pan, Y.; Chai, X.; Gao, Q.; Zhou, L.; Zhang, S.; Li, L.; Luan, S. Dynamic Interactions of Plant CNGC Subunits and Calmodulins Drive Oscillatory Ca ${ }^{2+}$ Channel Activities. Dev. Cell 2019, 48, 710-725.e5. [CrossRef] [PubMed]

21. Tian, W.; Hou, C.; Ren, Z.; Wang, C.; Zhao, F.; Dahlbeck, D.; Hu, S.; Zhang, L.; Niu, Q.; Li, L.; et al. A calmodulin-gated calcium channel links pathogen patterns to plant immunity. Nat. Cell Biol. 2019, 572, 131-135. [CrossRef]

22. Wu, F.; Chi, Y.; Jiang, Z.; Xu, Y.; Xie, L.; Huang, F.; Wan, D.; Ni, J.; Yuan, F.; Wu, X.; et al. Hydrogen peroxide sensor HPCA1 is an LRR receptor kinase in Arabidopsis. Nat. Cell Biol. 2020, 578, 577-581. [CrossRef]

23. Yang, Z.; Wang, C.; Xue, Y.; Liu, X.; Chen, S.; Song, C.; Yang, Y.; Guo, Y. Calcium-activated 14-3-3 proteins as a molecular switch in salt stress tolerance. Nat. Commun. 2019, 10,1-12. [CrossRef] 
24. Zhou, H.; Lin, H.; Chen, S.; Becker, K.; Yang, Y.; Zhao, J.; Kudla, J.; Schumaker, K.S.; Guo, Y. Inhibition of the Arabidopsis Salt Overly Sensitive Pathway by 14-3-3 Proteins. Plant Cell 2014, 26, 1166-1182. [CrossRef]

25. Kim, W.-Y.; Ali, Z.; Park, H.J.; Park, S.J.; Cha, J.-Y.; Perez-Hormaeche, J.; Quintero, F.J.; Shin, G.; Kim, M.R.; Qiang, Z.; et al. Release of SOS2 kinase from sequestration with GIGANTEA determines salt tolerance in Arabidopsis. Nat. Commun. 2013, 4, 1352. [CrossRef]

26. Tan, T.; Cai, J.; Zhan, E.; Yang, Y.; Zhao, J.; Guo, Y.; Zhou, H. Stability and localization of 14-3-3 proteins are involved in salt tolerance in Arabidopsis. Plant Mol. Biol. 2016, 92, 391-400. [CrossRef] [PubMed]

27. Barajas-Lopez, J.D.D.; Moreno, J.R.; Gamez-Arjona, F.M.; Pardo, J.M.; Punkkinen, M.; Zhu, J.-K.; Quintero, F.J.; Fujii, H. Upstream kinases of plant SnRKs are involved in salt stress tolerance. Plant J. 2017, 93, 107-118. [CrossRef] [PubMed]

28. Ma, L.; Ye, J.; Yang, Y.; Lin, H.; Yue, L.; Luo, J.; Long, Y.; Fu, H.; Liu, X.; Zhang, Y.; et al. The SOS2-SCaBP8 Complex Generates and Fine-Tunes an AtANN4-Dependent Calcium Signature under Salt Stress. Dev. Cell 2019, 48, 697-709.e5. [CrossRef] [PubMed]

29. Li, J.; Zhou, H.; Zhang, Y.; Li, Z.; Yang, Y.; Guo, Y. The GSK3-like Kinase BIN2 Is a Molecular Switch between the Salt Stress Response and Growth Recovery in Arabidopsis thaliana. Dev. Cell 2020, 55, 367-380.e6. [CrossRef] [PubMed]

30. Ren, X.-L.; Qi, G.-N.; Feng, H.-Q.; Zhao, S.; Zhao, S.-S.; Wang, Y.; Wu, W.-H. Calcineurin B-like protein CBL10 directly interacts with AKT1 and modulates K+homeostasis in Arabidopsis. Plant J. 2013, 74, 258-266. [CrossRef]

31. Nieves-Cordones, M.; Alemán, F.; Martínez, V.; Rubio, F. K+ uptake in plant roots. The systems involved, their regulation and parallels in other organisms. J. Plant Physiol. 2014, 171, 688-695. [CrossRef] [PubMed]

32. Xu, J.; Li, H.-D.; Chen, L.-Q.; Wang, Y.; Liu, L.-L.; He, L.; Wu, W.-H. A Protein Kinase, Interacting with Two Calcineurin B-like Proteins, Regulates K+ Transporter AKT1 in Arabidopsis. Cell 2006, 125, 1347-1360. [CrossRef] [PubMed]

33. Sánchez-Barrena, M.J.; Chaves-Sanjuan, A.; Raddatz, N.; Mendoza, I.; Cortés, Á.; Gago, F.; González-Rubio, J.M.; Benavente, J.L.; Quintero, F.J.; Pardo, J.M.; et al. Recognition and Activation of the Plant AKT1 Potassium Channel by the Kinase CIPK23. Plant Physiol. 2020, 182, 2143-2153. [CrossRef] [PubMed]

34. Cheong, Y.H.; Pandey, G.K.; Grant, J.J.; Batistic, O.; Li, L.; Kim, B.-G.; Lee, S.-C.; Kudla, J.; Luan, S. Two calcineurin B-like calcium sensors, interacting with protein kinase CIPK23, regulate leaf transpiration and root potassium uptake in Arabidopsis. Plant J. 2007, 52, 223-239. [CrossRef] [PubMed]

35. Lee, S.C.; Lan, W.-Z.; Kim, B.-G.; Li, L.; Cheong, Y.H.; Pandey, G.K.; Lu, G.; Buchanan, B.B.; Luan, S. A protein phosphorylation/dephosphorylation network regulates a plant potassium channel. Proc. Natl. Acad. Sci. USA 2007, 104, 15959-15964. [CrossRef]

36. Lan, W.Z.; Lee, S.C.; Che, Y.; Jiang, Y.; Luan, S. Mechanistic Analysis of AKT1 Regulation by the CBL-CIPK-PP2CA Interactions. Mol. Plant 2011, 4, 527-536. [CrossRef]

37. Latz, A.; Becker, D.; Hekman, M.; Müller, T.; Beyhl, D.; Marten, I.; Eing, C.; Fischer, A.; Dunkel, M.; Bertl, A.; et al. TPK1, a $\mathrm{Ca}^{2+}$-regulated Arabidopsis vacuole two-pore $\mathrm{K}+$ channel is activated by 14-3-3 proteins. Plant J. 2007, 52, 449-459. [CrossRef]

38. Latz, A.; Mehlmer, N.; Zapf, S.; Mueller, T.D.; Wurzinger, B.; Pfister, B.; Csaszar, E.; Hedrich, R.; Teige, M.; Becker, D. Salt Stress Triggers Phosphorylation of the Arabidopsis Vacuolar K+ Channel TPK1 by Calcium-Dependent Protein Kinases (CDPKs). Mol. Plant 2013, 6, 1274-1289. [CrossRef]

39. Ali, A.; Maggio, A.; Bressan, R.A.; Yun, D.-J. Role and Functional Differences of HKT1-Type Transporters in Plants under Salt Stress. Int. J. Mol. Sci. 2019, 20, 1059. [CrossRef]

40. Yang, Y.; Guo, Y. Unraveling salt stress signaling in plants. J. Integr. Plant Biol. 2018, 60, 796-804. [CrossRef]

41. Yang, Y.; Guo, Y. Elucidating the molecular mechanisms mediating plant salt-stress responses. New Phytol. 2017, 217, 523-539. [CrossRef] [PubMed]

42. Zhang, M.; Cao, Y.; Wang, Z.; Wang, Z.-Q.; Shi, J.; Liang, X.; Song, W.; Chen, Q.; Lai, J.; Jiang, C. A retrotransposon in an HKT1 family sodium transporter causes variation of leaf Na+exclusion and salt tolerance in maize. New Phytol. 2017, 217, 1161-1176. [CrossRef] [PubMed]

43. Chu, M.; Chen, P.; Meng, S.; Xu, P.; Lan, W. The Arabidopsis phosphatase PP2C49 negatively regulates salt tolerance through inhibition of AtHKT1;1. J. Integr. Plant Biol. 2021, 63, 528-542. [CrossRef] [PubMed]

44. Covington, M.F.; Maloof, J.N.; Straume, M.; Kay, S.A.; Harmer, S.L. Global transcriptome analysis reveals circadian regulation of key pathways in plant growth and development. Genome Biol. 2008, 9, R130. [CrossRef]

45. Sakuraba, Y.; Bülbül, S.; Piao, W.; Choi, G.; Paek, N. Arabidopsis EARLY FLOWERING 3 increases salt tolerance by suppressing salt stress response pathways. Plant J. 2017, 92, 1106-1120. [CrossRef]

46. Wei, H.; Wang, X.; He, Y.; Xu, H.; Wang, L. Clock component OsPRR73 positively regulates rice salt tolerance by modulating OsHKT2;1 -mediated sodium homeostasis. EMBO J. 2021, 40, e105086. [CrossRef]

47. Ayadi, M.; Brini, F.; Masmoudi, K. Overexpression of a Wheat Aquaporin Gene, TdPIP2;1, Enhances Salt and Drought Tolerance in Transgenic Durum Wheat cv. Maali. Int. J. Mol. Sci. 2019, 20, 2389. [CrossRef]

48. Marusig, D.; Tombesi, S. Abscisic Acid Mediates Drought and Salt Stress Responses in Vitis vinifera-A Review. Int. J. Mol. Sci. 2020, 21, 8648. [CrossRef]

49. Chen, X.; Ding, Y.; Yang, Y.; Song, C.; Wang, B.; Yang, S.; Guo, Y.; Gong, Z. Protein kinases in plant responses to drought, salt, and cold stress. J. Integr. Plant Biol. 2021, 63, 53-78. [CrossRef]

50. Zhou, X.; Naguro, I.; Ichijo, H.; Watanabe, K. Mitogen-activated protein kinases as key players in osmotic stress signaling. Biochim. Biophys. Acta Gen. Subj. 2016, 1860, 2037-2052. [CrossRef] 
51. Moustafa, K.; AbuQamar, S.; Jarrar, M.; Al-Rajab, A.J.; Trémouillaux-Guiller, J. MAPK cascades and major abiotic stresses. Plant Cell Rep. 2014, 33, 1217-1225. [CrossRef]

52. Pan, J.; Zhang, M.; Kong, X.; Xing, X.; Liu, Y.; Zhou, Y.; Liu, Y.; Sun, L.; Li, D. ZmMPK17, a novel maize group D MAP kinase gene, is involved in multiple stress responses. Planta 2011, 235, 661-676. [CrossRef]

53. Zhang, D.; Jiang, S.; Pan, J.; Kong, X.; Zhou, Y.; Liu, Y.; Li, D. The overexpression of a maize mitogen-activated protein kinase gene (ZmMPK5) confers salt stress tolerance and induces defence responses in tobacco. Plant Biol. 2013, 16, 558-570. [CrossRef] [PubMed]

54. Li, C.; Wang, G.; Zhao, J.; Zhang, L.; Ai, L.; Han, Y.; Sun, D.; Zhang, S.; Sun, Y. The Receptor-Like Kinase SIT1 Mediates Salt Sensitivity by Activating MAPK3/6 and Regulating Ethylene Homeostasis in Rice. Plant Cell 2014, 26, 2538-2553. [CrossRef] [PubMed]

55. Chen, K.; Gao, J.; Sun, S.; Zhang, Z.; Yu, B.; Li, J.; Xie, C.; Li, G.; Wang, P.; Bressan, R.A.; et al. The Calcium-Responsive Phospholipid-Binding BONZAI Proteins Control Global Osmotic Stress Responses in Plants Through Repression of Immune Signaling. SSRN Electron. J. 2020, 30, 4815. [CrossRef]

56. Nadarajah, K.K. ROS Homeostasis in Abiotic Stress Tolerance in Plants. Int. J. Mol. Sci. 2020, 21, 5208. [CrossRef]

57. Choudhury, F.K.; Rivero, R.M.; Blumwald, E.; Mittler, R. Reactive oxygen species, abiotic stress and stress combination. Plant J. 2016, 90, 856-867. [CrossRef]

58. Sofo, A.; Scopa, A.; Nuzzaci, M.; Vitti, A. Ascorbate Peroxidase and Catalase Activities and Their Genetic Regulation in Plants Subjected to Drought and Salinity Stresses. Int. J. Mol. Sci. 2015, 16, 13561-13578. [CrossRef] [PubMed]

59. Lu, Z.; Liu, D.; Liu, S. Two rice cytosolic ascorbate peroxidases differentially improve salt tolerance in transgenic Arabidopsis. Plant Cell Rep. 2007, 26, 1909-1917. [CrossRef]

60. Sharma, R.; Sahoo, A.; Devendran, R.; Jain, M. Over-Expression of a Rice Tau Class Glutathione S-Transferase Gene Improves Tolerance to Salinity and Oxidative Stresses in Arabidopsis. PLoS ONE 2014, 9, e92900. [CrossRef] [PubMed]

61. Xu, N.; Chu, Y.; Chen, H.; Li, X.; Wu, Q.; Jin, L.; Wang, G.; Huang, J. Rice transcription factor OsMADS25 modulates root growth and confers salinity tolerance via the ABA-mediated regulatory pathway and ROS scavenging. PLoS Genet. 2018, 14, e1007662. [CrossRef]

62. Seo, P.J.; Park, J.-M.; Kang, S.K.; Kim, S.-G.; Park, C.-M. An Arabidopsis senescence-associated protein SAG29 regulates cell viability under high salinity. Planta 2010, 233, 189-200. [CrossRef]

63. Chapman, J.M.; Muhlemann, J.K.; Gayomba, S.R.; Muday, G.K. RBOH-Dependent ROS Synthesis and ROS Scavenging by Plant Specialized Metabolites To Modulate Plant Development and Stress Responses. Chem. Res. Toxicol. 2019, 32, 370-396. [CrossRef] [PubMed]

64. Yu, Z.; Duan, X.; Luo, L.; Dai, S.; Ding, Z.; Xia, G. How Plant Hormones Mediate Salt Stress Responses. Trends Plant Sci. 2020, 25, 1117-1130. [CrossRef] [PubMed]

65. Jia, W.; Wang, Y.; Zhang, S.; Zhang, J. Salt-stress-induced ABA accumulation is more sensitively triggered in roots than in shoots J. Exp. Bot. 2002, 53, 2201-2206. [CrossRef] [PubMed]

66. Zhu, J.-K. Abiotic Stress Signaling and Responses in Plants. Cell 2016, 167, 313-324. [CrossRef] [PubMed]

67. Verma, V.; Ravindran, P.; Kumar, P.P. Plant hormone-mediated regulation of stress responses. BMC Plant Biol. 2016, 16, 1-10. [CrossRef]

68. Chen, K.; Li, G.; Bressan, R.A.; Song, C.; Zhu, J.; Zhao, Y. Abscisic acid dynamics, signaling, and functions in plants. J. Integr. Plant Biol. 2020, 62, 25-54. [CrossRef]

69. Huang, Y.; Jiao, Y.; Xie, N.; Guo, Y.; Zhang, F.; Xiang, Z.; Wang, R.; Wang, F.; Gao, Q.; Tian, L.; et al. OsNCED5, a 9-cisepoxycarotenoid dioxygenase gene, regulates salt and water stress tolerance and leaf senescence in rice. Plant Sci. 2019, 287, 110188. [CrossRef] [PubMed]

70. Takahashi, F.; Suzuki, T.; Osakabe, Y.; Betsuyaku, S.; Kondo, Y.; Dohmae, N.; Fukuda, H.; Yamaguchi-Shinozaki, K.; Shinozaki, K. A small peptide modulates stomatal control via abscisic acid in long-distance signalling. Nat. Cell Biol. 2018, 556, 235-238. [CrossRef]

71. Barrero, J.M.; Rodriguez, P.L.; Quesada, V.; Piqueras, P.; Ponce, M.R.; Micol, J.L. Both abscisic acid (ABA)-dependent and ABA-independent pathways govern the induction of NCED3, AAO3 and ABA1 in response to salt stress. Plant Cell Environ. 2006, 29, 2000-2008. [CrossRef]

72. Zhao, Y.; Zhang, Z.; Gao, J.; Wang, P.; Hu, T.; Wang, Z.; Hou, Y.-J.; Wan, Y.; Liu, W.; Xie, S.; et al. Arabidopsis Duodecuple Mutant of PYL ABA Receptors Reveals PYL Repression of ABA-Independent SnRK2 Activity. Cell Rep. 2018, 23, 3340-3351.e5. [CrossRef] [PubMed]

73. Wang, P.; Zhao, Y.; Li, Z.; Hsu, C.-C.; Liu, X.; Fu, L.; Hou, Y.-J.; Du, Y.; Xie, S.; Zhang, C.; et al. Reciprocal Regulation of the TOR Kinase and ABA Receptor Balances Plant Growth and Stress Response. Mol. Cell 2018, 69, 100-112.e6. [CrossRef] [PubMed]

74. Lin, Z.; Li, Y.; Zhang, Z.; Liu, X.; Hsu, C.; Du, Y.; Sang, T.; Zhu, C.; Wang, Y.; Satheesh, V.; et al. A RAF-SnRK2 kinase cascade mediates early osmotic stress signaling in higher plants. Nat. Commun. 2020, 11, 613. [CrossRef] [PubMed]

75. Krzywińska, E.; Bucholc, M.; Kulik, A.; Ciesielski, A.; Lichocka, M.; Dębski, J.; Ludwików, A.; Dadlez, M.; Rodriguez, P.L.; Dobrowolska, G. Phosphatase ABI1 and okadaic acid-sensitive phosphoprotein phosphatases inhibit salt stress-activated SnRK2.4 kinase. BMC Plant Biol. 2016, 16, 1-12. [CrossRef] [PubMed] 
76. Fujita, Y.; Yoshida, T.; Yamaguchi-Shinozaki, K. Pivotal role of the AREB/ABF-SnRK2 pathway in ABRE-mediated transcription in response to osmotic stress in plants. Physiol. Plant 2013, 147, 15-27. [CrossRef]

77. Yoshida, T.; Fujita, Y.; Sayama, H.; Kidokoro, S.; Maruyama, K.; Mizoi, J.; Shinozaki, K.; Yamaguchi-Shinozaki, K. AREB1, AREB2, and $\mathrm{ABF} 3$ are master transcription factors that cooperatively regulate ABRE-dependent ABA signaling involved in drought stress tolerance and require ABA for full activation. Plant J. 2010, 61, 672-685. [CrossRef]

78. Ohta, M.; Guo, Y.; Halfter, U.; Zhu, J.-K. A novel domain in the protein kinase SOS2 mediates interaction with the protein phosphatase 2C ABI2. Proc. Natl. Acad. Sci. USA 2003, 100, 11771-11776. [CrossRef]

79. Nolan, T.M.; Vukašinović, N.; Liu, D.; Russinova, E.; Yin, Y. Brassinosteroids: Multidimensional Regulators of Plant Growth, Development, and Stress Responses. Plant Cell 2020, 32, 295-318. [CrossRef]

80. Su, Q.; Zheng, X.; Tian, Y.; Wang, C. Exogenous Brassinolide Alleviates Salt Stress in Malus hupehensis Rehd. by Regulating the Transcription of NHX-Type $\mathrm{Na}+(\mathrm{K}+) / \mathrm{H}+$ Antiporters. Front. Plant Sci. 2020, 11, 38. [CrossRef]

81. Liu, J.; Gao, H.; Zheng, Q.; Wang, C.; Wang, X.; Wang, Q. Effects of 24-epibrassinolide on plant growth, osmotic regulation and ion homeostasis of salt-stressed canola. Plant Biol. 2013, 16, 440-450. [CrossRef]

82. Krishna, P.; Prasad, B.D.; Rahman, T. Brassinosteroid Action in Plant Abiotic Stress Tolerance. Methods Mol. Biol. 2017, 1564, 193-202. [CrossRef]

83. Fàbregas, N.; Lozano-Elena, F.; Blasco-Escámez, D.; Tohge, T.; Martínez-Andújar, C.; Albacete, A.; Osorio, S.; Bustamante, M.; Riechmann, J.L.; Nomura, T.; et al. Overexpression of the vascular brassinosteroid receptor BRL3 confers drought resistance without penalizing plant growth. Nat. Commun. 2018, 9, 1-13. [CrossRef]

84. Jia, C.; Zhao, S.; Bao, T.; Zhao, P.; Peng, K.; Guo, Q.; Gao, X.; Qin, J. Tomato BZR/BES transcription factor SlBZR1 positively regulates BR signaling and salt stress tolerance in tomato and Arabidopsis. Plant Sci. 2021, 302, 110719. [CrossRef]

85. Dong, N.Y.; Liu, D.; Zhang, X.; Yu, Z.; Huang, W.; Liu, J.; Yang, Y.; Meng, W.; Niu, M. Regulation of Brassinosteroid Signaling and Salt Resistance by SERK2 and Potential Utilization for Crop Improvement in Rice. Front. Plant Sci. 2020, 11, 621859. [CrossRef]

86. Shang, Y.; Yang, D.; Ha, Y.; Shin, H.-Y.; Nam, K.H. RPK1 and BAK1 sequentially form complexes with OST1 to regulate ABA-induced stomatal closure. J. Exp. Bot. 2019, 71, 1491-1502. [CrossRef]

87. Hu, Y.; Yu, D. BRASSINOSTEROID INSENSITIVE2 Interacts with ABSCISIC ACID INSENSITIVE5 to Mediate the Antagonism of Brassinosteroids to Abscisic Acid during Seed Germination in Arabidopsis. Plant Cell 2014, 26, 4394-4408. [CrossRef]

88. Cai, Z.L.; Liu, J.; Wang, H.; Yang, C.; Chen, Y.; Li, Y.; Pan, S.; Dong, R.; Tang, G.; Barajas-Lopez, J.; et al. GSK3-like kinases positively modulate abscisic acid signaling through phosphorylating subgroup III SnRK2s in Arabidopsis. Proc. Natl. Acad. Sci. USA 2014, 111, 9651-9656. [CrossRef] [PubMed]

89. Yang, X.; Bai, Y.; Shang, J.; Xin, R.; Tang, W. The antagonistic regulation of abscisic acid-inhibited root growth by brassinosteroids is partially mediated via direct suppression of ABSCISIC ACID INSENSITIVE 5 expression by BRASSINAZOLE RESISTANT 1. Plant Cell Environ. 2016, 39, 1994-2003. [CrossRef] [PubMed]

90. Yan, J.; Guan, L.; Sun, Y.; Zhu, Y.; Liu, L.; Lu, R.; Jiang, M.; Tan, M.; Zhang, A. Calcium and ZmCCaMK are involved in brassinosteroid-induced antioxidant defense in maize leaves. Plant Cell Physiol. 2015, 56, 883-896. [CrossRef] [PubMed]

91. Wang, X.; Mao, T. Understanding the functions and mechanisms of plant cytoskeleton in response to environmental signals. Curr. Opin. Plant Biol. 2019, 52, 86-96. [CrossRef] [PubMed]

92. Zhang, Q.; Lin, F.; Mao, T.; Nie, J.; Yan, M.; Yuan, M.; Zhang, W. Phosphatidic Acid Regulates Microtubule Organization by Interacting with MAP65-1 in Response to Salt Stress in Arabidopsis. Plant Cell 2012, 24, 4555-4576. [CrossRef]

93. Lian, N.; Wang, X.; Jing, Y.; Lin, J. Regulation of cytoskeleton-associated protein activities: Linking cellular signals to plant cytoskeletal function. J. Integr. Plant Biol. 2021, 63, 241-250. [CrossRef]

94. Wang, C.Z.; Huang, R.D. Cytoskeleton and plant salt stress tolerance. Plant Signal Behav. 2014, 6, 29-31. [CrossRef] [PubMed]

95. Ma, D.; Han, R. Microtubule organization defects in Arabidopsis thaliana. Plant Biol. 2020, 22, 971-980. [CrossRef] [PubMed]

96. Liu, S.G.; Zhu, D.Z.; Chen, G.H.; Gao, X.-Q.; Zhang, X.S. Disrupted actin dynamics trigger an increment in the reactive oxygen species levels in the Arabidopsis root under salt stress. Plant Cell Rep. 2012, 31, 1219-1226. [CrossRef] [PubMed]

97. Ye, J.; Zhang, W.; Guo, Y. Arabidopsis $\mathrm{SOS}_{3}$ plays an important role in salt tolerance by mediating calcium-dependent microfilament reorganization. Plant Cell Rep. 2013, 32, 139-148. [CrossRef]

98. Zhou, Y.; Yang, Z.; Guo, G.; Guo, Y. Microfilament Dynamics is Required for Root Growth under Alkaline Stress in Arabidopsis. J. Integr. Plant Biol. 2010, 52, 952-958. [CrossRef]

99. Wang, C.; Li, J.; Yuan, M. Salt Tolerance Requires Cortical Microtubule Reorganization in Arabidopsis. Plant Cell Physiol. 2007, 48, 1534-1547. [CrossRef]

100. Wang, C.; Zhang, L.; Yuan, M.; Ge, Y.; Liu, Y.; Fan, J.; Ruan, Y.; Cui, Z.; Tong, S.; Zhang, S. The microfilament cytoskeleton plays a vital role in salt and osmotic stress tolerance in Arabidopsis. Plant Biol. 2009, 12, 70-78. [CrossRef]

101. Qian, D.; Xiang, Y. Actin Cytoskeleton as Actor in Upstream and Downstream of Calcium Signaling in Plant Cells. Int. J. Mol. Sci. 2019, 20, 1403. [CrossRef]

102. Zhao, Y.; Pan, Z.; Zhang, Y.; Qu, X.; Yang, Y.; Jiang, X.; Huang, S.; Yuan, M.; Schumaker, K.S.; Guo, Y. The Actin-Related Protein2/3 Complex Regulates Mitochondrial-Associated Calcium Signaling during Salt Stress in Arabidopsis. Plant Cell 2013, 25, 4544-4559. [CrossRef]

103. Endler, A.; Kesten, C.; Schneider, R.; Zhang, Y.; Ivakov, A.; Froehlich, A.; Funke, N.; Persson, S. A Mechanism for Sustained Cellulose Synthesis during Salt Stress. Cell 2015, 162, 1353-1364. [CrossRef] 
104. Monniaux, M.; Hay, A. Cells, walls, and endless forms. Curr. Opin. Plant Biol. 2016, 34, 114-121. [CrossRef] [PubMed]

105. Liao, H.; Tang, R.; Zhang, X.; Luan, S.; Yu, F. FERONIA Receptor Kinase at the Crossroads of Hormone Signaling and Stress Responses. Plant Cell Physiol. 2017, 58, 1143-1150. [CrossRef]

106. Zhao, C.; Zayed, O.; Yu, Z.; Jiang, W.; Zhu, P.; Hsu, C.-C.; Zhang, L.; Tao, W.A.; Lozano-Durán, R.; Zhu, J.-K. Leucine-rich repeat extensin proteins regulate plant salt tolerance in Arabidopsis. Proc. Natl. Acad. Sci. USA 2018, 115, 13123-13128. [CrossRef]

107. Zhong, R.; Lee, C.; Ye, Z.-H. Evolutionary conservation of the transcriptional network regulating secondary cell wall biosynthesis. Trends Plant Sci. 2010, 15, 625-632. [CrossRef]

108. Du, Q.; Wang, H. The role of HD-ZIP III transcription factors and miR165/166 in vascular development and secondary cell wall formation. Plant Signal. Behav. 2015, 10, e1078955. [CrossRef]

109. Zhong, R.; Ye, Z.-H. MYB46 and MYB83 Bind to the SMRE Sites and Directly Activate a Suite of Transcription Factors and Secondary Wall Biosynthetic Genes. Plant Cell Physiol. 2012, 53, 368-380. [CrossRef] [PubMed]

110. Endler, A.; Persson, S. Cellulose Synthases and Synthesis in Arabidopsis. Mol. Plant 2011, 4, 199-211. [CrossRef]

111. Wang, L.; Hart, B.E.; Khan, G.A.; Cruz, E.R.; Persson, S.; Wallace, I.S. Associations between phytohormones and cellulose biosynthesis in land plants. Ann. Bot. 2020, 126, 807-824. [CrossRef]

112. Liu, C.Y.; Rao, X.L.; Li, L.G.; Dixon, R.A. Abscisic acid regulates secondary cell-wall formation and lignin deposition in Arabidopsis thaliana through phosphorylation of NST1. Proc. Natl. Acad. Sci. USA 2021, 118, e2010911118. [CrossRef] [PubMed]

113. Liu, Q.; Luo, L.; Zheng, L. Lignins: Biosynthesis and Biological Functions in Plants. Int. J. Mol. Sci. 2018, 19, 335. [CrossRef] [PubMed]

114. Endler, A.; Schneider, R.; Kesten, C.; Lampugnani, E.R.; Persson, S. The cellulose synthase companion proteins act nonredundantly with CELLULOSE SYNTHASE INTERACTING1/POM2 and CELLULOSE SYNTHASE 6. Plant Signal. Behav. 2016, 11, e1135281. [CrossRef]

115. Liu, Z.; Schneider, R.; Kesten, C.; Zhang, Y.; Somssich, M.; Zhang, Y.; Fernie, A.R.; Persson, S. Cellulose-Microtubule Uncoupling Proteins Prevent Lateral Displacement of Microtubules during Cellulose Synthesis in Arabidopsis. Dev. Cell 2016, 38, 305-315. [CrossRef]

116. Kesten, C.; Wallmann, A.; Schneider, R.; McFarlane, H.E.; Diehl, A.; Khan, G.A.; Van Rossum, B.-J.; Lampugnani, E.R.; Szymanski, W.G.; Cremer, N.; et al. The companion of cellulose synthase 1 confers salt tolerance through a Tau-like mechanism in plants. Nat. Commun. 2019, 10, 1-14. [CrossRef]

117. Chun, H.J.; Baek, D.; Cho, H.M.; Lee, S.H.; Jin, B.J.; Yun, D.-J.; Hong, Y.-S.; Kim, M.C. Lignin biosynthesis genes play critical roles in the adaptation of Arabidopsis plants to high-salt stress. Plant Signal. Behav. 2019, 14, 1625697. [CrossRef]

118. Yan, J.; Liu, Y.; Yang, L.; He, H.; Huang, Y.; Fang, L.; Scheller, H.V.; Jiang, M.; Zhang, A. Cell wall $\beta-1,4$-galactan regulated by the BPC1/BPC2-GALS1 module aggravates salt sensitivity in Arabidopsis thaliana. Mol. Plant 2021, 14, 411-425. [CrossRef]

119. Geng, G.; Lv, C.; Stevanato, P.; Li, R.; Liu, H.; Yu, L.; Wang, Y. Transcriptome Analysis of Salt-Sensitive and Tolerant Genotypes Reveals Salt-Tolerance Metabolic Pathways in Sugar Beet. Int. J. Mol. Sci. 2019, 20, 5910. [CrossRef]

120. Song, Q.; Joshi, M.; Joshi, V. Transcriptomic Analysis of Short-Term Salt Stress Response in Watermelon Seedlings. Int. J. Mol. Sci. 2020, 21, 6036. [CrossRef]

121. Xiong, Y.; Yan, H.; Liang, H.; Zhang, Y.; Guo, B.; Niu, M.; Jian, S.; Ren, H.; Zhang, X.; Li, Y.; et al. RNA-Seq analysis of Clerodendrum inerme (L.) roots in response to salt stress. BMC Genom. 2019, 20, 1-18. [CrossRef]

122. Tian, X.; Wang, Z.; Zhang, Q.; Ci, H.; Wang, P.; Yu, L.; Jia, G. Genome-wide transcriptome analysis of the salt stress tolerance mechanism in Rosa chinensis. PLoS ONE 2018, 13, e0200938. [CrossRef] [PubMed]

123. Cai, Z.-Q.; Gao, Q. Comparative physiological and biochemical mechanisms of salt tolerance in five contrasting highland quinoa cultivars. BMC Plant Biol. 2020, 20, 1-15. [CrossRef] [PubMed] 